\title{
Development of a Stereoselective Practical Synthetic Route to Indolmycin, a Candidate Anti-H. pylori Agent
}

\author{
Atsushi Hasuoka, ${ }^{a}$ Yutaka Nakayama, ${ }^{a}$ Mari Adachi,${ }^{b}$ Hidenori Kamiguchi,${ }^{c}$ and Keiji KamiYama $* a$ \\ Medicinal Chemistry Research Laboratories I, $^{a}$ Medicinal Chemistry Research Laboratories II, ${ }^{b}$ and Drug Analysis \& \\ Pharmacokinetics Research Laboratories, ${ }^{c}$ Takeda Chemical Industries Ltd., 2-17-85 Jusohonmachi, Yodogawa-ku, Osaka \\ 532-8686, Japan. Received August 3, 2001; accepted September 17, 2001
}

\begin{abstract}
A stereoselective practical synthetic route to indolmycin is described. The route is composed of the regioselective coupling of indolyl magnesium halide with a trans-epoxy ester, diastereoselective oxazolone ring formation with guanidine and amine exchange reaction with methylamine. In the coupling step, use of dichloromethane as co-solvent and conversion of the resulting hydroxy ester to the hydroxy acid for purification, make this process efficient and practical. The oxazolone ring is formed in good yield without epimerization at the $\mathrm{C5}$ position by treatment with guanidine and potassium tert-butoxide in tert-butanol at room temperature. In the final step, the amino group is efficiently converted to the methylamino group in aqueous methylamine solution at $5^{\circ} \mathrm{C}$. After examination of the route with racemates, indolmycin was synthesized stereoselectively in $22 \%$ total yield from optically active trans-epoxy ester. This route was applied to the preparation of the metabolites of indolmycin.
\end{abstract}

Key words indolmycin; diastereoselective synthesis; metabolite; amine exchange; guanidine

Indolmycin (1), isolated from an African strain of Streptomyces albus ${ }^{1)}$ exhibits antibacterial activity against Staphylococci. ${ }^{2)}$ Recently, our screening group found that $\mathbf{1}$ also has potent antibacterial activity against Helicobacter pylori $(H$. pylori) and it is a promising anti-H. pylori agent. ${ }^{3)}$

Although syntheses of $\mathbf{1}$, including its racemate, have been reported by several groups ${ }^{4)}$ none of them is satisfactory for large scale synthesis because of low diastereoselectivity or involving too many chemical processes. Therefore, it was necessary to develop a stereoselective practical synthetic route to $\mathbf{1}$ for further study. In this paper, we wish to report a convenient and practical stereoselective synthesis of $\mathbf{1}$ from epoxy ester $\mathbf{3}$ as a starting material, through hydroxy ester $\mathbf{2}$ (Chart 1), and we show its application to the preparation of metabolites.

\section{Chemistry}

Preparation of an Intermediate Hydroxy Ester ( \pm )-2 Initially we started to study the diastereoselective synthesis of $( \pm)-\mathbf{1}$ from $( \pm)-\mathbf{3}$ which was easily prepared from ethyl crotonate by oxidation with $m$-chloroperbenzoic acid. We investigated the condensation of indolyl magnesium halide with $( \pm)-\mathbf{3}$ although the coupling reaction of $( \pm)-\mathbf{3}$ with indole in the presence of Lewis acid was reported. ${ }^{4 e)}$ Indole was treated with methyl magnesium bromide in ethyl ether to form indolyl magnesium bromide and the complex was isolated. Addition of ( \pm )-3 to the reaction mixture gave the desired hydroxy ester $( \pm)-2$ in $48 \%$ yield after purification with silica gel column chromatography. The moderate yield was due to poor solubility of indolyl magnesium bromide in ethyl ether. It was reported that addition of dichloromethane to indolyl magnesium halide in ethyl ether brought the complex into a clear solution. ${ }^{5)}$ Addition of ( \pm )-3 to a solution of in-
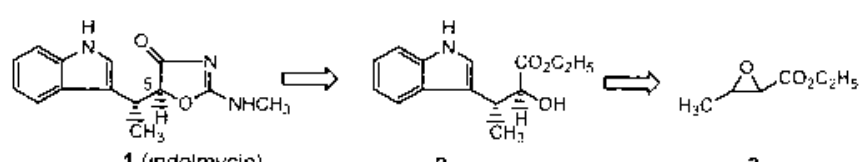

2

3

Chart 1 dolyl magnesium bromide in ethyl ether and dichloromethane gave $( \pm)-2$ in a better yield of $65 \%$. By increasing the amount of methyl magnesium bromide (2.2 eq to 3 ) the yield was improved to $79 \%$ (Chart 2). Although the yield was satisfactory, it was necessary to purify the crude product by silica gel column chromatography to remove unreacted indole and by-products. As it was found that the hydroxy acid $( \pm)-\mathbf{4}$ was easily purified by extraction and recrystallization, crude $( \pm)-2$ was hydrolyzed to $( \pm)-4$ and after purification, esterification of ( \pm )-4 gave pure ( \pm )-2 (Chart 2). Thus we accomplished the preparation of the racemic hydroxy ester $( \pm)-\mathbf{2}$.

Formation of the Oxazolone Ring Although Schach von Wittenau and Els ${ }^{4 e)}$ and Preobrazhenskaya et al. ${ }^{4 a)}$ reported that $( \pm)-1$ was prepared through formation of an oxazolone ring with $N, N^{\prime}$-dimethylguanidine from the hydroxy ester ( \pm )-2, the yields were very low, partly because the epimerization at $\mathrm{C} 5$ position of the oxazolone ring occurred in the alkaline medium. After intensive examination of the reaction, we found that epimerization was suppressed in tertbutanol below room temperature but the reaction was very slow (data was not shown). Therefore, we gave up the preparation of $( \pm)-\mathbf{1}$ from the hydroxy ester $( \pm)-2$ in one step.

Guanidine was expected to react faster than $N, N^{\prime}$-dimethylguanidine with $( \pm)-2$ to afford the amino derivative $( \pm)-5{ }^{4 a)}$ Therefore, we examined a 2 step conversion from $( \pm)-2$ to $( \pm)-1$ : the formation of the oxazolone ring with guanidine followed by an amine exchange reaction. Based on

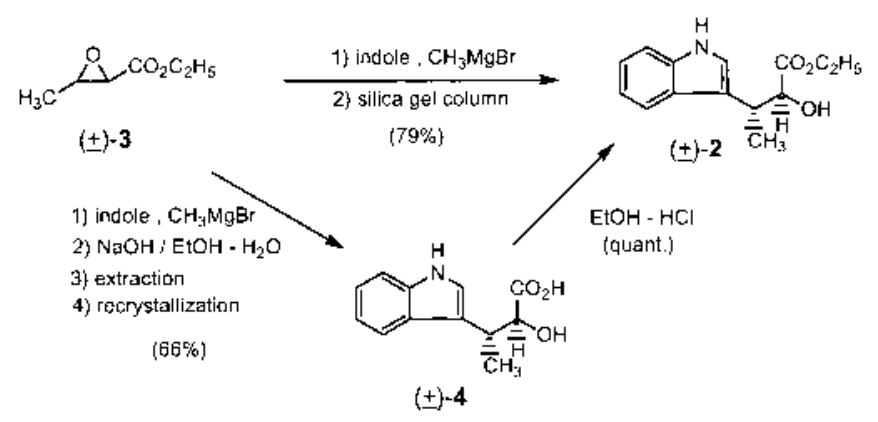

Chart 2 


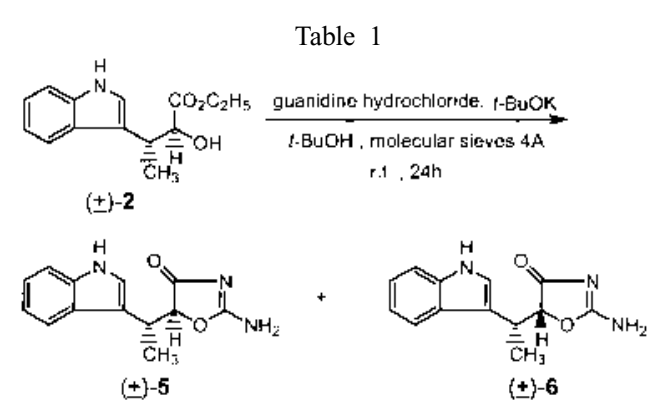

\begin{tabular}{cccccc}
\hline \hline Run & Guanidine & tert-BuOK & $( \pm)-\mathbf{2}^{a)}$ & $( \pm)-5^{a)}$ & $( \pm)-6^{a)}$ \\
\hline 1 & 2.0 eq & 2.1 eq & 23 & 59 & 3 \\
2 & 3.5 eq & 3.7 eq & 2 & 83 & 2 \\
3 & 5.0 eq & 5.3 eq & $<1$ & 86 & 3
\end{tabular}

a) HPLC yield based on ( \pm )-2.

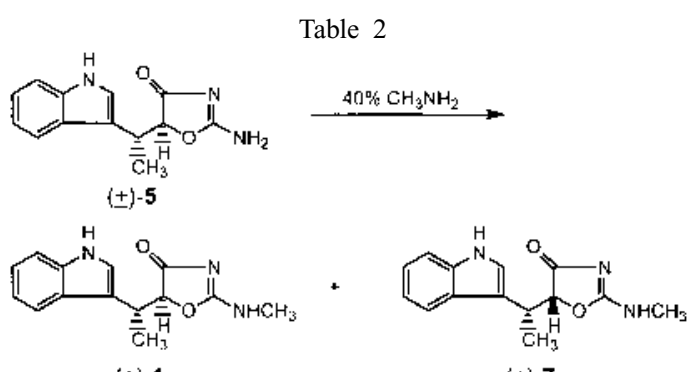

(t) -1

$( \pm)-7$

\begin{tabular}{clcccc}
\hline \hline Run & Solvent & Temp. $\left({ }^{\circ} \mathrm{C}\right)$ & Time $(\mathrm{h})$ & $( \pm)-\mathbf{1}^{a)}$ & $( \pm)-7^{a)}$ \\
\hline 1 & $\mathrm{CH}_{3} \mathrm{OH}$ & 5 & 24 & 84 & 5 \\
2 & $\mathrm{CH}_{3} \mathrm{OH}$ & 25 & 6 & 86 & 5 \\
3 & $\mathrm{H}_{2} \mathrm{O}$ & 5 & 4 & 93 & 3 \\
\hline
\end{tabular}

a) HPLC yield based on ( \pm$)-5$.

the information obtained above, the reaction was performed at room temperature with potassium tert-butoxide as base and tert-butanol as solvent (Table 1). Although the starting material still remained after $24 \mathrm{~h}$ with 2 eq of guanidine (run $1)$, the ratio of $( \pm)-5$ to its diastereomer $( \pm)-6$ was satisfactorily high (ca. 20:1). By increasing the amount of guanidine and potassium tert-butoxide (runs 2,3) we obtained $( \pm)-5$, almost diastereoselectively in $86 \%$ yield in $24 \mathrm{~h}$.

Amine Exchange Reaction It has been reported that the 2-(dimethylamino)-4(5H)-oxazolone derivative of $( \pm)$-1 was converted to $( \pm)-\mathbf{1}$ quantitatively in liquid methylamine without significant epimerization. ${ }^{4 c)}$ Although a similar amine exchange reaction was expected to occur in the case of $( \pm)-5$, the amino group was not transformed into the methylamino group under the same conditions. Next we treated ( \pm )-5 with commercially available $40 \%$ methylamine solution in methanol at $5{ }^{\circ} \mathrm{C}$ for $24 \mathrm{~h}$ and $( \pm)-1$ was obtained in $84 \%$, with $5 \%$ of its diastereomer $( \pm)-7$ (Table 2 ). Although higher temperature $\left(25^{\circ} \mathrm{C}\right)$ accelerated the reaction, the ratio of $( \pm)-1$ to $( \pm)-7$ was not improved. Treatment of $( \pm)-5$ with commercially available $40 \%$ methylamine in water at $5{ }^{\circ} \mathrm{C}$ for $4 \mathrm{~h}$ afforded $( \pm)-1$ in $93 \%$ with only $3 \%$ of its diastereomer $( \pm)-7$.

Total Synthesis of Optically Active Indolmycin 1 As described above, racemic indolmycin was synthesized dia-
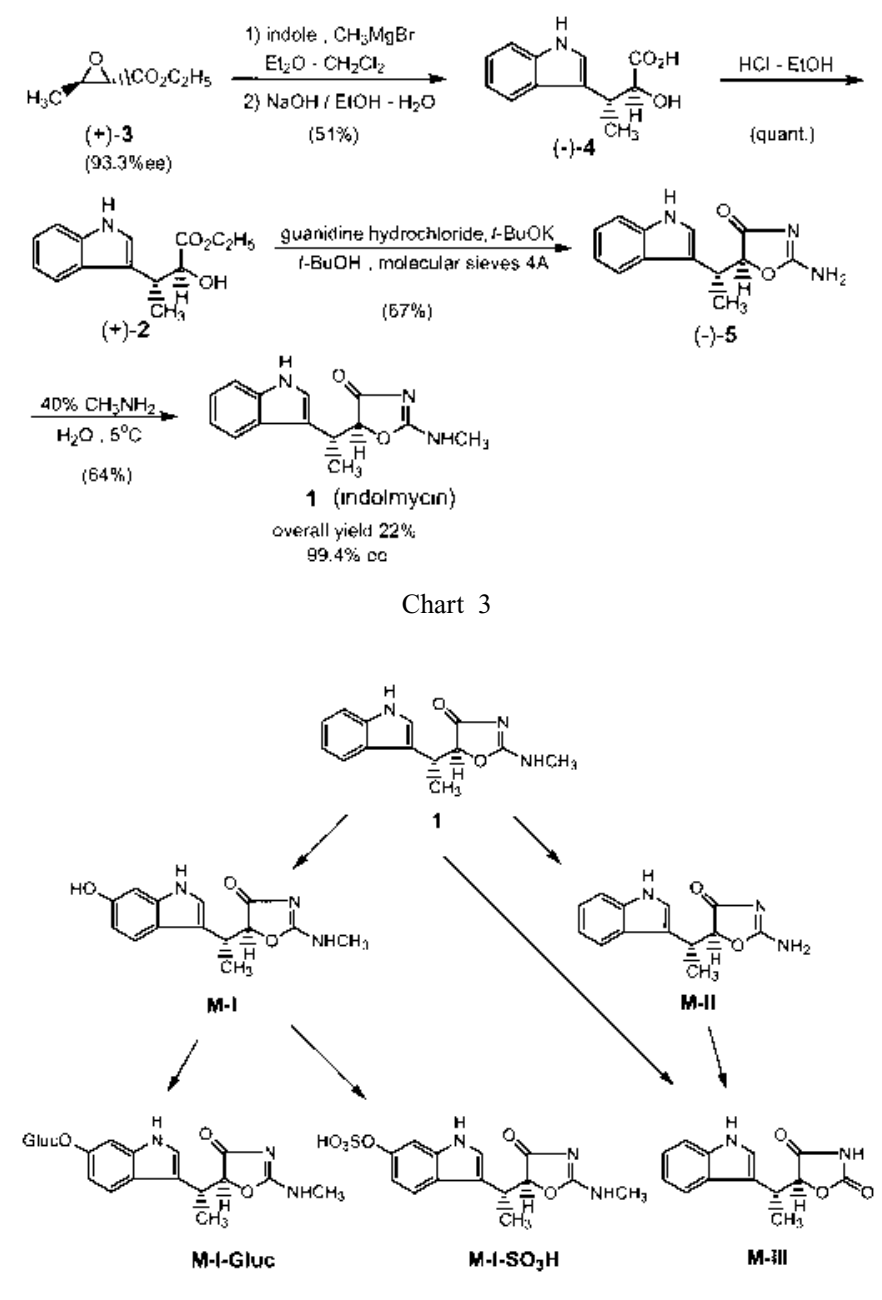

Chart 4

stereoselectively in good yield from the racemic trans-epoxy ester (土)-3. Then, we confirmed that this synthetic route was efficient for large-scale preparation of optically active indolmycin 1 from the optically active $(+)-3$. Some preparations of the optically active trans-epoxy ester $(+)-3$ have been reported. ${ }^{6}$

Treatment of the epoxy ester $(+)-3(93.3 \%$ ee) with indolyl magnesium bromide in ethyl ether and dichloromethane followed by hydrolysis afforded the crude acid (-)-4. After recrystallization from water, pure (-)-4 was obtained in 51\% yield which was lower than for the racemate due to loss during recrystallization. Esterification of (-)-4 gave practically pure $(+)-\mathbf{2}$ quantitatively as a syrup. Treatment of $(+)-\mathbf{2}$ with guanidine in tert-butanol under the reaction conditions described above afforded the pure amino derivative (-)-5 in $67 \%$ after crystallization from ethyl acetate. Finally $(-)-5$ was treated with $40 \%$ methylamine solution in water at $5^{\circ} \mathrm{C}$ to give crude indolmycin $\mathbf{1}$, which was recrystallized from methanol-water to afford pure indolmycin 1 (99.4\% ee, total yield $22 \%$ from $(+)-3)$. Thus the stereoselective practical synthetic route to $\mathbf{1}$, shown in Chart 3, was established.

Synthesis of Metabolites of Indolmycin Five metabolites shown in Chart 4 were detected in rat serum and/or excreta after oral administration of indolmycin and were characterized by liquid chromatography/ion-trap mass spectrometry (LC/IT/MS) and ${ }^{1} \mathrm{H}-\mathrm{NMR}$. M-I is the 6-hydroxy deriva- 


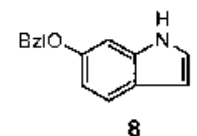

8
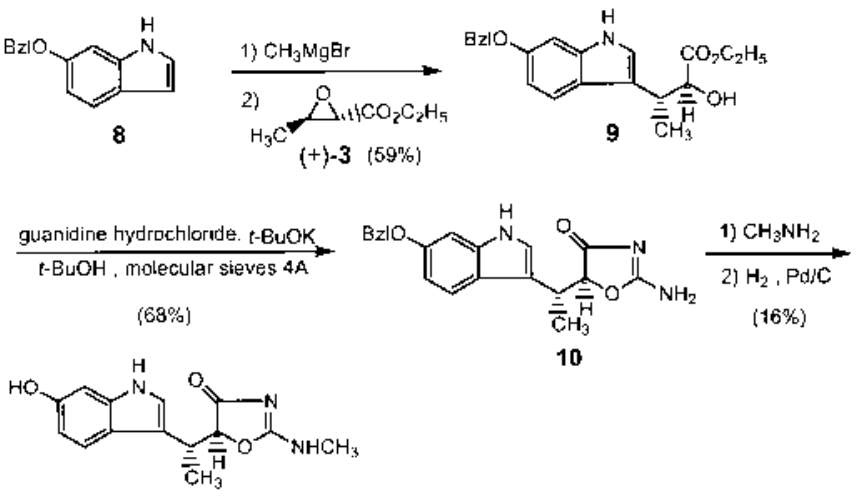

M-I

Chart 5
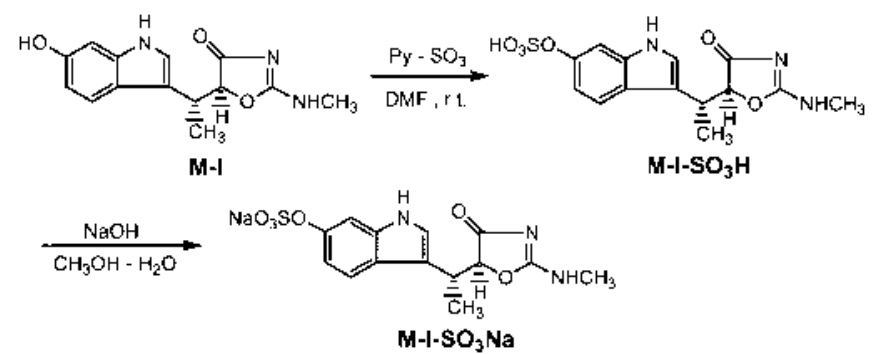

Chart 6
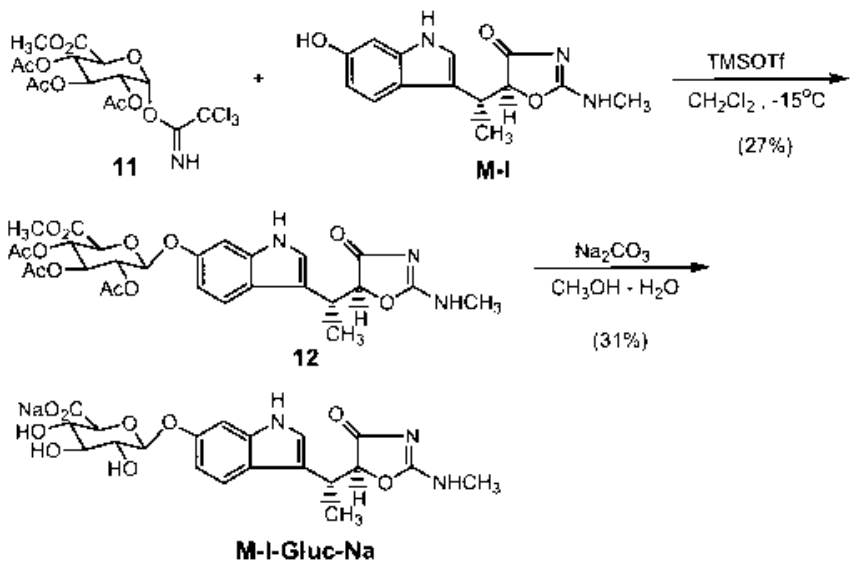

Chart 7

tive of 1, which was prepared by applying our synthetic route for 1 to 6-benzyloxyindole $\mathbf{8},{ }^{7)}$ as shown in Chart 5. The sulfate of M-I was prepared by treatment of M-I with pyridine sulfur trioxide complex (Chart 6) and the glucuronide of M-I was obtained by treatment of M-I with the imidate $\mathbf{1 1}^{8)}$ in the presence of trimethylsilyl trifluoromethanesulfonate (TMSOTf) followed by hydrolysis (Chart 7). The $N$ demethylated metabolite M-II was the intermediate (-)-5 of our synthesis of indolmycin 1. M-III was obtained by acetylation of the methylamino group of $\mathbf{1}$ followed by treatment with hydrochloric acid (Chart 8). The structure of metabolites M-I, M-II, M-III, M-I-Gluc, and M-I-SO $\mathrm{S}_{3} \mathrm{H}$ were confirmed by comparison of the mass spectra and the HPLC retention time with the synthetic compounds.

In conclusion, we have established a stereoselective practical synthetic route to indolmycin 1, a candidate anti- $H$. pylori agent. This study has opened the way to synthesize $\mathbf{1}$ on a
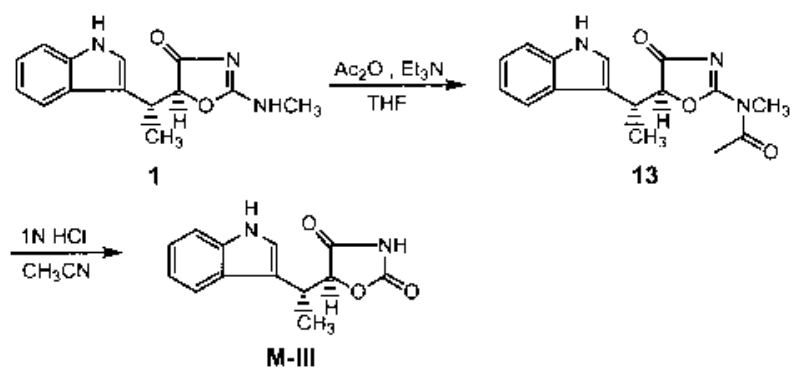

Chart 8

large-scale in 5 steps, with high purity, from the optically active epoxy ester $(+)-3$. Moreover, this route is useful for preparation of the metabolites of $\mathbf{1}$.

\section{Experimental}

${ }^{1} \mathrm{H}-\mathrm{NMR}$ spectra were recorded on a Varian Gemini $200(200 \mathrm{MHz})$ with tetramethylsilane as an internal standard and chemical shifts $(\delta)$ are expressed in ppm. The following abbreviations are used; s: singlet, d: doublet, t: triplet, q: quartet, br s: broad singlet, dd: double doublet, dt: double triplet, dq: double quartet, m: multiplet. Infrared absorption spectra (IR) were measured on a FTIR-8200PC type IR spectrophotometer made by Shimadzu. Elemental analyses were performed by Takeda Analytical Research Laboratories, Ltd. Optical rotations were recorded on a DIP-370 digital polarimeter made by JASCO. Melting points were determined using a Micro Melting Point Apparatus made by Yanaco. Kieselgel 60 made by Merck was used as the support for column chromatography.

(2S,3R)-2-Hydroxy-3-(1H-indol-3-yl)butanoic Acid ((-)-4) To a solution of methyl magnesium bromide in ethyl ether $(2.93 \mathrm{M}, 35 \mathrm{ml})$ was added indole $(5.86 \mathrm{~g}, 50.0 \mathrm{mmol})$ in $50 \mathrm{ml}$ of dichloromethane, dropwise over $45 \mathrm{~min}$ under $\mathrm{N}_{2}$ atmosphere at $0^{\circ} \mathrm{C}$. After stirring for $30 \mathrm{~min}$, the solution was cooled to $-20^{\circ} \mathrm{C}$ and then ethyl $(2 S, 3 R)-2,3$-epoxybutanoate $((+)-3$, $5.47 \mathrm{~g}, 42.0 \mathrm{mmol})$ in dichloromethane $(50 \mathrm{ml})$ was added dropwise over $1.5 \mathrm{~h}$ at $-20^{\circ} \mathrm{C}$. After stirring for $1 \mathrm{~h}, 1 \mathrm{~N} \mathrm{HCl}(150 \mathrm{ml})$ was added. The organic layer was separated and the aqueous layer was extracted with dichloromethane $(50 \mathrm{ml})$. The combined organic layer was dried over anhydrous $\mathrm{MgSO}_{4}$ and concentrated in vacuo. To the residue were added ethanol $(60 \mathrm{ml})$ and $1 \mathrm{~N} \mathrm{NaOH}(75 \mathrm{ml})$ and the mixture was stirred for $16 \mathrm{~h}$ at room temperature. After removal of the solvent by evaporation, water $(60 \mathrm{ml})$ was added and the aqueous solution was washed with ethyl acetate $(100 \mathrm{ml})$ twice. The aqueous layer was adjusted to $\mathrm{pH} 2-3$ with $4 \mathrm{~N} \mathrm{HCl}$ and extracted with ethyl acetate $(100 \mathrm{ml})$ twice. The combined extract was dried over anhydrous $\mathrm{MgSO}_{4}$ and evaporated under reduced pressure. The residue was recrystallized from water $(80 \mathrm{ml})$ to give $(2 S, 3 R)-2$-hydroxy-3-(1Hindol-3-yl)butanoic acid ((-)-4, 4.72 g, 51\%). ${ }^{1} \mathrm{H}-\mathrm{NMR}$ (DMSO- $\left.d_{6}\right) \delta: 1.25$ $(3 \mathrm{H}, \mathrm{d}, J=7.0 \mathrm{~Hz}), 3.41(1 \mathrm{H}, \mathrm{m}), 4.19(1 \mathrm{H}, \mathrm{d}, J=4.6 \mathrm{~Hz}), 6.93-7.14(3 \mathrm{H}$, m), $7.33(1 \mathrm{H}, \mathrm{d}, J=7.4 \mathrm{~Hz}), 7.54(1 \mathrm{H}, \mathrm{d}, J=7.4 \mathrm{~Hz}), 10.79(1 \mathrm{H}$, br s). IR $\left(\mathrm{KBr}, \mathrm{cm}^{-1}\right): 3429,3397,1726,1458$. Anal. Calcd for $\mathrm{C}_{12} \mathrm{H}_{13} \mathrm{NO}_{3}: \mathrm{C}, 65.74$; H, 5.98; N, 6.39. Found: C, 65.48; H, 6.10; N, 6.34. $[\alpha]_{\mathrm{D}}^{22}-9.3^{\circ}(c=2.0$, methanol) $\left[\right.$ lit. $^{4 e)}[\alpha]_{\mathrm{D}}^{25}-10^{\circ}\left(c=2.0\right.$, methanol)]. mp $180.5-181^{\circ} \mathrm{C}$ (lit. $^{4 e)}$ $\left.181-182^{\circ} \mathrm{C}\right)$.

Ethyl (2S,3R)-2-Hydroxy-3-(1H-indol-3-yl)butanoate ((+)-2) Acetyl chloride $(15 \mathrm{ml}, 211 \mathrm{mmol})$ was added to ethanol $(75 \mathrm{ml})$ at $0{ }^{\circ} \mathrm{C}$. After stirring for $30 \mathrm{~min},(2 S, 3 R)-2$-hydroxy-3-(1H-indol-3-yl)butanoic acid $((-)-4$, $4.42 \mathrm{~g}, 20.2 \mathrm{mmol})$ was added at $0^{\circ} \mathrm{C}$. The solution was stirred for $6 \mathrm{~h}$ at room temperature. After removal of the solvent, the residue was dissolved into ethyl acetate $(150 \mathrm{ml})$. The organic layer was washed with aqueous saturated $\mathrm{NaHCO}_{3}$ solution $(50 \mathrm{ml})$ twice, water $(50 \mathrm{ml})$ and brine $(40 \mathrm{ml})$ and then dried over anhydrous $\mathrm{MgSO}_{4}$. The solution was concentrated in vacuo and the resulting oil was dried at $60^{\circ} \mathrm{C}$ in an oil bath with stirring in vacuo to give ethyl $(2 S, 3 R)-2-h y d r o x y-3-(1 H$-indol-3-yl)butanoate $((+)-2,4.98 \mathrm{~g}$, quant.). ${ }^{1} \mathrm{H}-\mathrm{NMR}\left(\mathrm{CDCl}_{3}\right), \delta: 1.27(3 \mathrm{H}, \mathrm{d}, J=7.4 \mathrm{~Hz}), 1.34(3 \mathrm{H}, \mathrm{d}, J=$ $7.0 \mathrm{~Hz}), 2.75(1 \mathrm{H}, \mathrm{d}, J=5.6 \mathrm{~Hz}), 3.63(1 \mathrm{H}, \mathrm{dq}, J=3.2,7.0 \mathrm{~Hz}), 4.25(2 \mathrm{H}, \mathrm{q}$, $J=7.4 \mathrm{~Hz}), 4.48(1 \mathrm{H}, \mathrm{dd}, J=3.2,5.6 \mathrm{~Hz}), 7.0-7.3(3 \mathrm{H}, \mathrm{m}), 7.37(1 \mathrm{H}, \mathrm{d}$, $J=7.0 \mathrm{~Hz}), 7.68(1 \mathrm{H}, \mathrm{d}, J=7.4 \mathrm{~Hz}), 8.05\left(1 \mathrm{H}\right.$, br s). IR $\left(\mathrm{KBr}, \mathrm{cm}^{-1}\right): 3400$, 3337, 1728, 1456. Anal. Calcd for $\mathrm{C}_{14} \mathrm{H}_{17} \mathrm{NO}_{3}: \mathrm{C}, 68.00 ; \mathrm{H}, 6.93 ; \mathrm{N}, 5.66$. Found: C, 67.79; H, 7.21; N, 5.56. $[\alpha]_{\mathrm{D}}^{24}+5.2^{\circ}(c=1.11$, methanol).

(5S)-2-Amino-5-[(1R)-1-(1H-indol-3-yl)ethyl]-2-oxazolin-4-one ((-)-5) To a solution of guanidine hydrochloride $(9.56 \mathrm{~g}, 100 \mathrm{mmol})$ in tert-butanol $(40 \mathrm{ml})$ were added potassium tert-butoxide $(11.2 \mathrm{~g}, 99.8 \mathrm{mmol})$ and molecu- 
lar sieves 4A $(10 \mathrm{~g})$. The mixture was stirred for $3 \mathrm{~d}$ at room temperature and ethyl $(2 S, 3 R)$-2-hydroxy-3-(1H-indol-3-yl)butanoate $((+)-2,4.98 \mathrm{~g}, 20.1$ $\mathrm{mmol})$ in tert-butanol $(30 \mathrm{ml})$ was added. After stirring for $7.5 \mathrm{~h}$ at room temperature, the reaction mixture was poured into ice cold saturated ammonium chloride $(400 \mathrm{ml})$. After filtering, the filtrate was extracted with ethyl acetate-isopropanol $(250 \mathrm{ml}, 4: 1)$. The organic layer was washed with aqueous $5 \% \mathrm{NaHCO}_{3}$ solution $(100 \mathrm{ml})$ and water and then dried over anhydrous $\mathrm{MgSO}_{4}$. After evaporation, the residue was dissolved in hot ethyl acetate $(23 \mathrm{ml})$ and allowed to stand. The resulting crystals were collected by filtration and washed with ethyl acetate $(4 \mathrm{ml})$ to give $(5 S)$-2-amino-5-[(1R)-1(1H-indol-3-yl)ethyl]-2-oxazolin-4-one $((-)-5,3.26 \mathrm{~g}, \quad 67 \%) .{ }^{1} \mathrm{H}-\mathrm{NMR}$ $\left(\mathrm{DMSO}-d_{6}\right) \delta: 1.20(3 \mathrm{H}, \mathrm{d}, J=7.4 \mathrm{~Hz}), 3.57(1 \mathrm{H}, \mathrm{dq}, J=2.6,7.4 \mathrm{~Hz}), 4.91$ $(1 \mathrm{H}, \mathrm{d}, J=2.6 \mathrm{~Hz}), 6.94-7.16(3 \mathrm{H}, \mathrm{m}), 7.35(1 \mathrm{H}, \mathrm{d}, J=7.2 \mathrm{~Hz}), 7.58(1 \mathrm{H}, \mathrm{d}$, $J=7.4 \mathrm{~Hz}), 8.25(1 \mathrm{H}$, br s$), 8.41\left(1 \mathrm{H}\right.$, br s). IR $\left(\mathrm{KBr}, \mathrm{cm}^{-1}\right): 3588,3261$, 1724, 1638, 1541. Anal. Calcd for $\mathrm{C}_{13} \mathrm{H}_{13} \mathrm{~N}_{3} \mathrm{O}_{2}$ : C, 59.76; H, 5.79; N, 16.08 . Found: C, 59.65; H, 5.68; N, 16.07. $[\alpha]_{\mathrm{D}}^{22}-174.0^{\circ}(c=2.0$, methanol). mp $180.5-181.5^{\circ} \mathrm{C}$.

(5S)-5-[(1R)-1-(1H-Indol-3-yl)ethyl]-2-methylamino-2-oxazolin-4-one (Indolmycin 1) (5S)-2-Amino-5-[(1R)-1-(1H-indol-3-yl)ethyl]-2-oxazolin4-one $((-)-5,3.10 \mathrm{~g}, 12.7 \mathrm{mmol})$ was dissolved into $40 \%$ methylamine in water $(20 \mathrm{ml})$. The solution was allowed to stand in a refrigerator for $5 \mathrm{~h}$ at $5{ }^{\circ} \mathrm{C}$. The reaction mixture was concentrated to half volume under reduced pressure without heating. The resulting crystals were collected by filtration and recrystallized from methanol-water $(6 \mathrm{ml}, 2: 1)$. The white crystals were collected by filtration and dried to give $(5 S)-5-[(1 R)-1-(1 H$-indol-3-yl)ethyl]2-methylamino-2-oxazolin-4-one (indolmycin 1, 2.10 g, 64\%). ${ }^{1} \mathrm{H}-\mathrm{NMR}$ $\left(\mathrm{DMSO}-d_{6}\right) \delta: 1.19,1.25(3 \mathrm{H}, \mathrm{d}, J=7.0 \mathrm{~Hz}), 2.70-2.82(3 \mathrm{H}, \mathrm{m}), 3.59(1 \mathrm{H}$, $\mathrm{m}), 4.90,4.94(1 \mathrm{H}, \mathrm{d}, J=2.4 \mathrm{~Hz}), 6.95-7.19(3 \mathrm{H}, \mathrm{m}), 7.35(1 \mathrm{H}, \mathrm{d}$, $J=7.8 \mathrm{~Hz}), 7.58(1 \mathrm{H}, \mathrm{d}, J=7.8 \mathrm{~Hz}), 8.30(1 \mathrm{H}, \mathrm{s}), 8.64(1 \mathrm{H}, \mathrm{br} \mathrm{s}), 10.93(1 \mathrm{H}$, br s). IR $\left(\mathrm{KBr}, \mathrm{cm}^{-1}\right): 3266,1730,1604$. Anal. Calcd for $\mathrm{C}_{14} \mathrm{H}_{15} \mathrm{~N}_{3} \mathrm{O}_{2}: \mathrm{C}$, 65.35; H, 5.88; N, 16.33. Found: C, 65.28; H, 5.73; N, 16.06. $[\alpha]_{\mathrm{D}}^{22}-212.5^{\circ}$ $\left(c=2.0\right.$, methanol) $\left[\right.$ lit. $^{1 a)}[\alpha]_{\mathrm{D}}^{25}-214^{\circ}(c=2.0$, methanol $\left.)\right] \cdot \operatorname{mp} 206-207^{\circ} \mathrm{C}$ (lit. $\left.{ }^{1 a)} 209-210^{\circ} \mathrm{C}\right)$.

Ethyl (2S,3R)-3-[6-(Benzyloxy)-1H-indol-3-yl]-2-hydroxybutanoate (9) To a solution of methyl magnesium bromide in ethyl ether $(2.93 \mathrm{M}, 74 \mathrm{ml})$ was added 6-benzyloxyindole $(\mathbf{8}, 19.4 \mathrm{~g}, 86.9 \mathrm{mmol})$ in $190 \mathrm{ml}$ of dichloromethane dropwise for $45 \mathrm{~min}$ under $\mathrm{N}_{2}$ atmosphere at $0^{\circ} \mathrm{C}$. After stirring for $30 \mathrm{~min}$, the solution was cooled to $-20^{\circ} \mathrm{C}$ and then ethyl $(2 S, 3 R)-2,3$-epoxybutanoate $((+)-3,22.6 \mathrm{~g}, 174 \mathrm{mmol})$ in dichloromethane $(200 \mathrm{ml})$ was added dropwise for $3 \mathrm{~h}$ at $-20^{\circ} \mathrm{C}$. After stirring for $1 \mathrm{~h}, 1 \mathrm{~N}$ $\mathrm{HCl}(300 \mathrm{ml})$ was added. The organic layer was separated and the aqueous layer was extracted with dichloromethane $(300 \mathrm{ml})$ twice. The combined organic layer was dried over anhydrous $\mathrm{MgSO}_{4}$ and concentrated in vacuo. The residue was purified by silica gel column chromatography (hexaneethyl acetate) to give ethyl $(2 S, 3 R)$-3-[6-(benzyloxy)- $1 H$-indol-3-yl]-2-hydroxybutanoate $(9,18.1 \mathrm{~g}, 59 \%)$. ${ }^{1} \mathrm{H}-\mathrm{NMR}\left(\mathrm{CDCl}_{3}\right) \delta: 1.27(3 \mathrm{H}, \mathrm{d}, J=7.2$ $\mathrm{Hz}), 1.32(3 \mathrm{H}, \mathrm{d}, J=7.2 \mathrm{~Hz}), 2.74(1 \mathrm{H}, \mathrm{d}, J=5.6 \mathrm{~Hz}), 3.57(1 \mathrm{H}, \mathrm{dq}, J=3.2$, $7.2 \mathrm{~Hz}), 4.24(2 \mathrm{H}, \mathrm{q}, J=7.2 \mathrm{~Hz}), 4.46(1 \mathrm{H}, \mathrm{dd}, J=3.2,5.6 \mathrm{~Hz}), 5.10(2 \mathrm{H}, \mathrm{s})$, $6.85-6.90(2 \mathrm{H}, \mathrm{m}), 7.01(1 \mathrm{H}, \mathrm{m}), 7.23-7.57(6 \mathrm{H}, \mathrm{m}), 7.91(1 \mathrm{H}, \mathrm{br}) . \mathrm{IR}$ $\left(\mathrm{KBr}, \mathrm{cm}^{-1}\right)$ : 3364, 1732, 1628. Anal. Calcd for $\mathrm{C}_{21} \mathrm{H}_{23} \mathrm{NO}_{4} 0.1 \mathrm{H}_{2} \mathrm{O}: \mathrm{C}$, 71.01; H, 6.58; N, 3.94. Found: C, 70.87; H, 6.75; N, 3.73. $[\alpha]_{\mathrm{D}}^{25}+6.3^{\circ}$ $(c=0.104$, methanol).

(5S)-2-Amino-5-[(1R)-1-(6-benzyloxy-1H-indol-3-yl)ethyl]-2-oxazolin4-one (10) To a solution of guanidine hydrochloride $(17.6 \mathrm{~g}, 184 \mathrm{mmol})$ in tert-butanol $(180 \mathrm{ml})$ were added potassium tert-butoxide $(20.7 \mathrm{~g}, 184 \mathrm{mmol})$ and molecular sieves 4A (10 g). The mixture was stirred for $1 \mathrm{~d}$ at room temperature and ethyl (2S,3R)-3-[6-(benzyloxy)-(1H-indol-3-yl)]-2-hydroxybutanoate $(9,12.9 \mathrm{~g}, 36.5 \mathrm{mmol})$ in tert-butanol $(120 \mathrm{ml})$ was added. After stirring for $20 \mathrm{~h}$ at room temperature, the reaction mixture was poured into icesaturated ammonium chloride $(600 \mathrm{ml})$. After filtering, the filtrate was extracted with ethyl acetate-ethanol $(400 \mathrm{ml}, 7: 1)$ twice. The organic layer was washed with aqueous saturated $\mathrm{NaHCO}_{3}$ solution and dried over anhydrous $\mathrm{MgSO}_{4}$. After evaporation, the residue was dissolved in hot ethyl acetate $(75 \mathrm{ml})$ and allowed to stand. The resulting crystals were collected by filtration and washed with ethyl acetate to give (5S)-2-amino-5-[(1R)-1-(6benzyloxy-1 $H$-indol-3-yl)ethyl]-2-oxazolin-4-one (10, 8.62 g, 68\%). ${ }^{1} \mathrm{H}-\mathrm{NMR}$ $\left(\mathrm{DMSO}-d_{6}\right) \delta: 1.18(3 \mathrm{H}, \mathrm{m}), 3.51(1 \mathrm{H}, \mathrm{m}), 4.89(1 \mathrm{H}, \mathrm{d}, J=2.4 \mathrm{~Hz}), 5.11$ $(2 \mathrm{H}, \mathrm{s}), 6.74(1 \mathrm{H}, \mathrm{dd}, J=2.2,8.6 \mathrm{~Hz}), 6.93-7.03(3 \mathrm{H}, \mathrm{m}), 7.31-7.49(5 \mathrm{H}$, $\mathrm{m}), 8.30\left(2 \mathrm{H}\right.$, br s), $10.73\left(1 \mathrm{H}\right.$, br s). IR $\left(\mathrm{KBr}, \mathrm{cm}^{-1}\right): 3317,1738,1658$, 1556. Anal. Calcd for $\mathrm{C}_{20} \mathrm{H}_{19} \mathrm{~N}_{3} \mathrm{O}_{3}$ : C, 67.03; H, 5.62; N, 11.72. Found: C, $67.22 ; \mathrm{H}, 5.53 ; \mathrm{N}, 11.49 .[\alpha]_{\mathrm{D}}^{24}-121.5^{\circ}(c=0.2$, methanol). mp 217$218^{\circ} \mathrm{C}$.

$(5 S)-5-[(1 R)-1-(6-H y d r o x y-1 H$-indol-3-yl)ethyl]-2-methylamino-2-oxazolin-4-one (M-I) (5S)-2-Amino-5-[(1R)-1-(6-benzyloxy-1H-indol-3-yl)- ethyl]-2-oxazolin-4-one $(\mathbf{1 0}, 2.27 \mathrm{~g}, 6.45 \mathrm{mmol})$ was dissolved into $40 \%$ methylamine in methanol and allowed to stand for $8 \mathrm{~h}$ at $5{ }^{\circ} \mathrm{C}$. The reaction mixture was concentrated to half volume under reduced pressure without heating, water was added to the residue and then extracted with ethyl acetate-tetrahydrofuran $(5: 1)$ twice. The combined organic layer was dried over anhydrous $\mathrm{MgSO}_{4}$ and evaporated under reduced pressure. The residue was dissolved into ethanol-tetrahydrofuran $(7: 3,100 \mathrm{ml})$ and the solution was stirred for $14 \mathrm{~h}$ at room temperature with $10 \% \mathrm{Pd} / \mathrm{C}(1.10 \mathrm{~g})$ under $\mathrm{H}_{2}$ atmosphere. The reaction mixture was filtered and evaporated under reduced pressure. Purification by column chromatography with silica gel $(60 \mathrm{~g}$, hexane : acetone $=1: 2$ ) and MCI gel HP-20 (acetonitrile $:$ water $=1: 3$ ) followed by crystallization from acetonitrile-water $(1: 3)$ gave white crystals of (5S)-5-[(1R)-1-(6-hydroxy-1H-indol-3-yl)ethyl]-2-methylamino-2-oxazolin4-one (M-I, $250 \mathrm{mg}, 16 \%) .{ }^{1} \mathrm{H}-\mathrm{NMR}$ (DMSO- $\left.d_{6}\right) \delta: 1.14(2 \mathrm{H}, \mathrm{d}, J=7.2 \mathrm{~Hz})$, $1.20(1 \mathrm{H}, \mathrm{d}, J=7.0 \mathrm{~Hz}), 2.78(1 / 3 \mathrm{H}, \mathrm{s}), 2.80(2 / 3 \mathrm{H}, \mathrm{s}), 3.50(1 \mathrm{H}, \mathrm{m}), 4.87$ $(1 / 3 \mathrm{H}, \mathrm{d}, J=2.6 \mathrm{~Hz}), 4.90(2 / 3 \mathrm{H}, \mathrm{d}, J=2.2 \mathrm{~Hz}), 6.52(1 \mathrm{H}, \mathrm{dd}, J=1.8,8.4 \mathrm{~Hz})$, $6.70(1 \mathrm{H}, \mathrm{d}, J=1.8 \mathrm{~Hz}), 6.91(2 / 3 \mathrm{H}, \mathrm{br} \mathrm{s}), 6.94(1 / 3 \mathrm{H}, \mathrm{br} \mathrm{s}), 7.33(1 \mathrm{H}, \mathrm{d}$, $J=8.4 \mathrm{~Hz}), 8.63(1 / 3 \mathrm{H}$, br s), $8.69(2 / 3 \mathrm{H}$, br s), $8.89(1 \mathrm{H}, \mathrm{br} \mathrm{s})$. IR $(\mathrm{KBr}$, $\left.\mathrm{cm}^{-1}\right): 3320,3202,1723$, 1624. Anal. Calcd for $\mathrm{C}_{14} \mathrm{H}_{15} \mathrm{~N}_{3} \mathrm{O}_{3} 1.0 \mathrm{H}_{2} \mathrm{O}: \mathrm{C}$, 57.72; H, 5.88; N, 14.42. Found: C, 57.48; H, 5.76; N, 14.14. $[\alpha]_{\mathrm{D}}^{22}-185.2^{\circ}$ $\left(c=0.1\right.$, methanol). $\mathrm{mp} 148-149^{\circ} \mathrm{C}$.

Sodium 3-\{(1R)-1-[(5S)-2-Methylamino-4-oxo-4,5-dihydro-1,3-oxazol5-yl]ethyl $\}-1 H$-indol-6-yl Sulfate (M-I-SO $\left.{ }_{3} \mathbf{N a}\right)$ To a solution of $(5 S)-5$ [(1R)-1-(6-hydroxy-1H-indol-3-yl)ethyl]-2-methylamino-2-oxazolin-4-one (M-I, $635 \mathrm{mg}, 2.32 \mathrm{mmol}$ ) in $N, N$-dimethylformamide (DMF)-pyridine $(4: 1,13 \mathrm{ml})$ was added pyridine- $\mathrm{SO}_{3}$ complex $(2.00 \mathrm{~g}, 12.6 \mathrm{mmol})$ and the mixture was stirred for $60 \mathrm{~h}$ at room temperature. Water $(15 \mathrm{ml})$ was added at $0{ }^{\circ} \mathrm{C}$ and concentrated in vacuo. The reaction mixture was purified by column chromatography with adsorbent resin (Sepabeads SP-207, water: acetonitrile $=25: 1$ ) and preparative HPLC (YMC ODS-A, $250 \mathrm{~mm} \times 20 \mathrm{~mm}$, water: acetonitrile $=97: 3$ ). After evaporation under reduced pressure, the residue was dissolved in methanol and filtered. Concentration of the filtrate in vacuo gave a syrup which was powdered by treatment with ethyl acetate. The powder was dissolved into methanol $(10 \mathrm{ml})$ and $1 \mathrm{~N} \mathrm{NaOH}(1.5 \mathrm{ml})$ was added at $0{ }^{\circ} \mathrm{C}$. After removal of the solvent, the mixture was purified by column chromatography with Sephadex LH-20 (water). After evaporation under reduced pressure, the residue was dissolved into water $(9 \mathrm{ml})$ and lyophilized to give sodium 3-\{(1R)-1-[(5S)-2-methylamino-4-oxo-4,5-dihydro-1,3-oxazol-5-yl]ethyl $\}-1 H$-indol-6-yl sulfate (M-I-SO $3 \mathrm{Na}, 332 \mathrm{mg}, 63 \%)$. ${ }^{1} \mathrm{H}-\mathrm{NMR}$ (DMSO- $\left.d_{6}\right) \delta: 1.35(2 \mathrm{H}, \mathrm{d}, J=7.2 \mathrm{~Hz}), 1.40(1 \mathrm{H}, \mathrm{d}, J=7.2 \mathrm{~Hz})$, $2.83(2 \mathrm{H}, \mathrm{s}), 2.84(1 \mathrm{H}, \mathrm{s}), 3.64-3.82(1 \mathrm{H}, \mathrm{m}), 5.00(2 / 3 \mathrm{H}, \mathrm{d}, J=2.6 \mathrm{~Hz})$, $5.05(1 / 3 \mathrm{H}, \mathrm{d}, J=3.0 \mathrm{~Hz}), 7.01(1 / 3 \mathrm{H}, \mathrm{d}, J=8.7 \mathrm{~Hz}), 7.02(2 / 3 \mathrm{H}, \mathrm{d}, J=$ $8.7 \mathrm{~Hz}), 7.10(2 / 3 \mathrm{H}, \mathrm{s}), 7.13(1 / 3 \mathrm{H}, \mathrm{br} \mathrm{s}), 7.33(1 / 3 \mathrm{H}, \mathrm{s}), 7.34(2 / 3 \mathrm{H}, \mathrm{s}), 7.54$ $(2 / 3 \mathrm{H}, \mathrm{d}, J=8.7 \mathrm{~Hz}), 7.56(1 / 3 \mathrm{H}, \mathrm{d}, J=8.7 \mathrm{~Hz}) . \mathrm{IR}\left(\mathrm{KBr}, \mathrm{cm}^{-1}\right): 3304,1730$, 1628, 1493. Anal. Calcd for $\mathrm{C}_{14} \mathrm{H}_{14} \mathrm{~N}_{3} \mathrm{O}_{6} \mathrm{SNa} 1.5 \mathrm{H}_{2} \mathrm{O}: \mathrm{C}, 41.79 ; \mathrm{H}, 4.26 ; \mathrm{N}$, 10.44. Found: C, $41.84 ; \mathrm{H}, 4.22 ; \mathrm{N}, 10.41 .[\alpha]_{\mathrm{D}}^{25}-139.6^{\circ}\left(c=0.1, \mathrm{H}_{2} \mathrm{O}\right)$.

Methyl $(2 S, 3 S, 4 S, 5 R, 6 S)-3,4,5-\operatorname{Tris}($ acetoxy $)-6-[(3-\{(1 R)-1-[(5 S)-2-$ (methylamino)-4-oxo-4,5-dihydro-1,3-oxazol-5-yl] ethyl $\}$-1 $H$-indol-6yl)oxy]tetrahydro-2 $\mathrm{H}$-pyran-2-carboxylate (12) A suspension of (5S)-5[(1R)-1-(6-hydroxy-1H-indol-3-yl)ethyl]-2-methylamino-2-oxazolin-4-one (M-I, $250 \mathrm{mg}, 0.915 \mathrm{mmol})$ in dichloromethane $(8 \mathrm{ml})$ was cooled at $-15^{\circ} \mathrm{C}$ in an acetone-ice bath. TMSOTf $(0.180 \mathrm{ml}, 0.931 \mathrm{mmol})$ was added and the mixture was stirred for $30 \mathrm{~min}$ at $-15^{\circ} \mathrm{C}$ under argon atmosphere. A solution of methyl 2,3,4-tri- $O$-acetyl-1- $O$-(trichloroacetimidoyl)- $\alpha$-D-glucopyranuronate $(\mathbf{1 1}, 715 \mathrm{mg}, 1.49 \mathrm{mmol})$ in dichloromethane $(2 \mathrm{ml})$ was added and stirred for $2.5 \mathrm{~h}$ at $-15^{\circ} \mathrm{C}$. Ethyl acetate $(50 \mathrm{ml})$ was added to the reaction mixture and washed with $0.1 \mathrm{~N} \mathrm{HCl}$, saturated aqueous $\mathrm{NaHCO}_{3}$ solution and brine and then dried over $\mathrm{MgSO}_{4}$. After removal of the solvent, the residue was purified by silica gel column chromatography $(20 \mathrm{~g}$, $\mathrm{CH}_{2} \mathrm{Cl}_{2}$ : methanol $\left.=90: 10\right)$ to give methyl $(2 S, 3 S, 4 S, 5 R, 6 S)-3,4,5$-tris(acetoxy)-6-[(3-\{(1R)-1-[(5S)-2-(methylamino)-4-oxo-4,5-dihydro-1,3-oxazol-5yl] ethyl $\}-1 H$-indol-6-yl)oxy]tetrahydro-2 $H$-pyran-2-carboxylate $145 \mathrm{mg}, 27 \%) .{ }^{1} \mathrm{H}-\mathrm{NMR}\left(\mathrm{CDCl}_{3}\right) \delta: 1.34(1.5 \mathrm{H}, \mathrm{d}, J=7.0 \mathrm{~Hz}), 1.44(1.5 \mathrm{H}, \mathrm{d}$, $J=7.4 \mathrm{~Hz}), 2.05-2.09(9 \mathrm{H}, \mathrm{m}), 2.84(1.5 \mathrm{H}, \mathrm{s}), 2.95(1.5 \mathrm{H}, \mathrm{d}, J=4.8 \mathrm{~Hz})$, $3.66(1.5 \mathrm{H}, \mathrm{s}), 3.73(1.5 \mathrm{H}, \mathrm{s}), 3.79(1 \mathrm{H}, \mathrm{m}), 4.22(1 \mathrm{H}, \mathrm{d}, J=9.6 \mathrm{~Hz}), 4.87$, $4.90(1 \mathrm{H}, \mathrm{d}, J=2.6 \mathrm{~Hz}), 5.13(1 \mathrm{H}, \mathrm{dd}, J=5.4,7.4 \mathrm{~Hz}), 5.20-5.40(1 \mathrm{H}, \mathrm{m})$, $6.80(1 \mathrm{H}, \mathrm{dd}, J=2.2,8.4 \mathrm{~Hz}), 7.03-7.07(2 \mathrm{H}, \mathrm{m}), 7.51(0.5 \mathrm{H}, \mathrm{d}, J=8.4 \mathrm{~Hz})$, $7.52(0.5 \mathrm{H}, \mathrm{d}, J=8.8 \mathrm{~Hz}), 8.37(1 \mathrm{H}, \mathrm{m}) . \mathrm{IR}\left(\mathrm{KBr}, \mathrm{cm}^{-1}\right): 3198,1759,1622$, 1221. Anal. Calcd for $\mathrm{C}_{27} \mathrm{H}_{31} \mathrm{~N}_{3} \mathrm{O}_{12} 1.5 \mathrm{H}_{2} \mathrm{O}$ : C, 52.60; H, 5.56; N, 6.82 . Found: $\mathrm{C}, 52.74 ; \mathrm{H}, 5.43$; N, 6.54. $[\alpha]_{\mathrm{D}}^{24}-103.1^{\circ}(c=0.22$, methanol)

Sodium $(2 S, 3 S, 4 S, 5 R, 6 S)-3,4,5$-Trihydroxy-6-[(3-\{(1R)-1-[(5S)-2-(methylamino)-4-oxo-4,5-dihydro-1,3-oxazol-5-yl]ethyl $\}-1 H$-indol-6-yl)oxy]tetrahydro-2H-pyran-2-carboxylate (M-I-GlucNa) To a solution of methyl $(2 S, 3 S, 4 S, 5 R, 6 S)-3,4,5$-tris(acetoxy)-6-[(3-\{(1R)-1-[(5S)-2-(methyl- 
amino)-4-oxo-4,5-dihydro-1,3-oxazol-5-yl]ethyl $\}$ - $1 H$-indol-6-yl)oxy]tetrahydro- $2 \mathrm{H}$-pyran-2-carboxylate $(\mathbf{1 2}, 400 \mathrm{mg}, 0.678 \mathrm{mmol})$ in methanol $(14 \mathrm{ml})$ was added sodium carbonate $(198 \mathrm{mg}, 1.87 \mathrm{mmol})$ in water $(6 \mathrm{ml})$ at $0{ }^{\circ} \mathrm{C}$. After stirring for $3.5 \mathrm{~h}$ at $0{ }^{\circ} \mathrm{C}$, the solution was adjusted to $\mathrm{pH} 5$ with $1 \mathrm{~N} \mathrm{HCl}$ and concentrated under reduced pressure. The residue was purified by preparative HPLC (YMC ODS-A, $250 \mathrm{~mm} \times 20 \mathrm{~mm}$, water: acetonitrile $=97: 3)$ followed by lyophilization to give sodium $(2 S, 3 S, 4 S, 5 R, 6 S)$ 3,4,5-trihydroxy-6-[(3-\{(1R)-1-[(5S)-2-(methylamino)-4-oxo-4,5-dihydro1,3-oxazol-5-yl]ethyl $\}$ - $1 H$-indol-6-yl)oxy]tetrahydro-2 $H$-pyran-2-carboxylate (M-I-GlucNa, $93 \mathrm{mg}, 31 \%) .{ }^{1} \mathrm{H}-\mathrm{NMR}$ (DMSO- $\left.d_{6}\right) \delta: 1.17,1.26(3 \mathrm{H}, \mathrm{d}$, $J=7.0 \mathrm{~Hz}), 2.76-2.81(3 \mathrm{H}, \mathrm{m}), 3.60-6.80(5 \mathrm{H}, \mathrm{m}), 4.74(1 \mathrm{H}, \mathrm{dd}, J=2.6$, $6.8 \mathrm{~Hz}), 4.87,4.92(1 \mathrm{H}, \mathrm{d}, J=2.6 \mathrm{~Hz}), 4.99(1 \mathrm{H}, \mathrm{br} \mathrm{s}), 5.23(1 \mathrm{H}, \mathrm{br} \mathrm{s}), 6.80$ $(1 \mathrm{H}, \mathrm{m}), 7.05(2 \mathrm{H}, \mathrm{m}), 7.46(1 \mathrm{H}, \mathrm{d}, J=8.4 \mathrm{~Hz}), 10.78(1 \mathrm{H}, \mathrm{br} \mathrm{s}) . \mathrm{IR}(\mathrm{KBr}$, $\left.\mathrm{cm}^{-1}\right)$ : 3300, 3192, 1730, 1626, 1413. Anal. Calcd for $\mathrm{C}_{20} \mathrm{H}_{22} \mathrm{~N}_{3} \mathrm{O}_{9} \mathrm{Na}$ $2.5 \mathrm{H}_{2} \mathrm{O}: \mathrm{C}, 46.51 ; \mathrm{H}, 5.27 ; \mathrm{N}, 8.14$. Found: $\mathrm{C}, 46.56 ; \mathrm{H}, 5.19 ; \mathrm{N}, 8.24 .[\alpha]_{\mathrm{D}}^{25}$ $-219.3^{\circ}\left(c=0.01, \mathrm{H}_{2} \mathrm{O}\right)$.

(5S)-5-[(1R)-1-(1H-Indol-3-yl)ethyl]-1,3-oxazolidine-2,4-dione (M-III) To a solution of $(5 S)-5-[(1 R)-1-(1 H$-indol-3-yl)ethyl]-2-methylamino-2-oxazolin-4-one (indolmycin 1, $5.00 \mathrm{~g}, 19.4 \mathrm{mmol}$ ) in tetrahydrofuran (THF) $(65 \mathrm{ml})$ were added at $0{ }^{\circ} \mathrm{C}$ triethylamine $(8.13 \mathrm{ml}, 58.3 \mathrm{mmol})$ and acetic anhydride $(3.66 \mathrm{ml}, 38.8 \mathrm{mmol})$. The mixture was stirred for $30 \mathrm{~min}$ at $0{ }^{\circ} \mathrm{C}$ and then for $5 \mathrm{~h}$ at room temperature. After addition of ethyl acetate $(520 \mathrm{ml})$ and water $(130 \mathrm{ml})$ at $0{ }^{\circ} \mathrm{C}$, the reaction mixture was stirred for $30 \mathrm{~min}$. The ethyl acetate layer was separated, washed with brine $(130 \mathrm{ml})$ and dried over anhydrous $\mathrm{MgSO}_{4}$. After concentration under reduced pressure, the residue was crystallized from isopropyl ether and the crystals were collected by filtration. To a solution of the crystals in acetonitrile $(100 \mathrm{ml})$ was added $1 \mathrm{~N} \mathrm{HCl}$ $(40 \mathrm{ml})$ and stirred for $110 \mathrm{~min}$ at room temperature. After removal of the solvent by concentration, water $(100 \mathrm{ml})$ was added and the aqueous layer was extracted with ethyl acetate $(250 \mathrm{ml})$. The ethyl acetate layer was washed with water $(50 \mathrm{ml})$ an brine $(50 \mathrm{ml})$ and dried over anhydrous $\mathrm{MgSO}_{4}$. After concentration in vacuo, the residue was crystallized from isopropyl ether-hexane. Recrystallization from methanol-water afforded (5S)5-[(1R)-1-(1H-indol-3-yl)ethyl]-1,3-oxazolidine-2,4-dione (M-III, $2.25 \mathrm{~g}$, 47\%). ${ }^{1} \mathrm{H}-\mathrm{NMR}$ (DMSO- $\left.d_{6}\right) \delta: 1.36(3 \mathrm{H}, \mathrm{d}, J=7.2 \mathrm{~Hz}), 3.67(1 \mathrm{H}, \mathrm{m}), 5.20$
$(1 \mathrm{H}, \mathrm{d}, J=3.2 \mathrm{~Hz}), 6.95-7.13(2 \mathrm{H}, \mathrm{m}), 7.18(1 \mathrm{H}, \mathrm{d}, J=2.4 \mathrm{~Hz}), 7.36(1 \mathrm{H}, \mathrm{d}$, $J=7.4 \mathrm{~Hz}), 7.57(1 \mathrm{H}, \mathrm{d}, J=7.6 \mathrm{~Hz}), 10.98(1 \mathrm{H}, \mathrm{br} \mathrm{s}), 11.76(1 \mathrm{H}, \mathrm{br} \mathrm{s}) . \mathrm{IR}$ $\left(\mathrm{KBr}, \mathrm{cm}^{-1}\right): 3393,3258,1815,1746,1460$. Anal. Calcd for $\mathrm{C}_{13} \mathrm{H}_{12} \mathrm{~N}_{2} \mathrm{O}_{3}: \mathrm{C}$, 63.93; H, 4.95; N, 11.47. Found: C, 63.89; H, 4.85; N, 11.50. $[\alpha]_{\mathrm{D}}^{22}-180.8^{\circ}$ $\left(c=1.08\right.$, methanol). mp $179-179.5^{\circ} \mathrm{C}$

\section{References}

1) a) Rao K. V., Antibiot. Chemother., 10, 312-315 (1960); b) Schach von Wittenau M., Els H., J. Am. Chem. Soc., 83, 4678- 4680 (1961); c) Chan T. H., Hill R. K., J. Org. Chem., 35, 3519-3521 (1970).

2) Marsh W. S., Garretson A. L., Wesel E. M., Antibiot. Chemother., 10, 316-320 (1960).

3) Kanamaru T., Nakano Y., Toyoda Y., Miyagawa K., Tada M., Kaisho T., Nakao M., Antimicrob. Agents Chemother., 45, 2455-2459 (2001).

4) a) Preobrazhenskaya M. N., Balashova E. G., Turchin K. F., Padeiskaya E. N., Yvarova N. V., Pershin G. N., Suvorov M. N., Tetrahedron, 24, 6131-6143 (1968); b) Takeda T., Mukaiyama T., Chem. Lett., 1980, 163-166; c) Dirlam J. P., Clark D. A., Hecker S. J., J. Org. Chem., 51, 4920 - 4924 (1986); d) Shue Y.-K., Tetrahedron Lett., 37, 6447-6448 (1996); e) Schach von Wittenau M., Els H., J. Am. Chem. Soc., 85, 3425-3431 (1963).

5) Bader H., Oroshnik W., J. Am. Chem. Soc., 81, 163-167 (1959).

6) a) Sharpless K. B., Ambergm W., Bennani Y. L., Crispino G. A., Hartung J., Jeong K.-S., Kwong H.-L., Morikawa K., Wang Z.-M., Xu D., Zhang X.-L., J. Org. Chem., 57, 2768-2771 (1992); b) Fleming P. R., Sharpless K. B., ibid., 56, 2869-2875 (1991); c) Genet J.-P., Cano Andrade M. C., Ratovelomanana-Vidal V., Tetrahedron Lett., 36, 2063-2066 (1995); d) Akita H., Kawaguchi T., Enoki Y., Oishi T., Chem. Pharm. Bull., 38, 323-328 (1990).

7) Teranishi K., Nakatsuka S., Goto T., Synthesis, 1984, 1018-1020.

8) a) Bollenback G. N., Long J. W., Benjamin D. G., Lindquist J. A., J. Am. Chem. Soc., 77, 3310-3315 (1955); b) Nudelman A., Herzig J., Gottlieb H. E., Carbohydr. Res., 162, 145-152 (1987); c) Schmitt R. R., Grundler G., Synthesis, 1981, 885-887. 